\title{
ISOLATION OF SMALL VIRUSES RESEMBLING ASTROVIRUSES AND CALICIVIRUSES FROM ACUTE ENTERITIS OF CALVES
}

\author{
G. N. WOODE AND J. C. BRIDGER \\ Agricultural Research Council, Institute for Research on Animal Diseases, Compton, \\ Newbury, Berkshire RG16 ONN
}

\section{Plate XL}

THE pathogenic role of viruses in diarrhoea of human infants, calves, pigs and lambs has been established. The viruses concerned include the coronaviruses that cause transmissible gastroenteritis of pigs and calf diarrhoea (Woode, 1969; Mebus et al., 1973; Woode, Bridger and Meyling, 1978). Parvoviruses have occasionally been reported as causing calf diarrhoea (Storz and Bates, 1973). Many publications have associated rotaviruses with diarrhoea of children, calves, pigs, mice, lambs, foals, monkeys, rabbits, and wild animals such as deer and pronghorn antelopes. Experimental studies have shown that rotaviruses can behave as primary pathogens, but in outbreaks of disease they are frequently associated with coronaviruses and unidentified small viruses, in addition to Escherichia coli, salmonellae and coccidia (Woode et al., 1974; Acres et al., 1975; Morin, Larivière and Lallier, 1976; Scherrer et al., 1976; Flewett and Woode, 1978).

Small unidentified viruses have been found in faeces of children with diarrhoea and the names " astrovirus" and "calicivirus " were applied to them (Madeley and Cosgrove, 1975, 1976; Madeley et al., 1977). Similar viruses were seen in faeces from calves infected with bovine rotavirus or bovine coronavirus (Woode et al., 1974; Bridger, Woode and Meyling, 1978). After removal of the known pathogens, rotavirus and coronavirus, faecal preparations containing the small viruses were still pathogenic to gnotobiotic calves. We now report studies attempting to identify the small viruses and to determine their pathogenic effect on gnotobiotic calves.

\section{MATERIALS AND METHODS}

Viruses. Three herds with a history of calf diarrhoea were studied. Diarrhoeic samples from one calf in each herd were shown to contain small round viruses (SRV) by electronmicroscopy. In the first sample, rotaviruses were also observed (Woode et al., 1974) and in the second, coronaviruses (Bridger, Woode and Meyling, in press); in the third sample only SRV were seen. All three samples were obtained from calves less than 7 days old.

Animal inoculation. Faecal preparations containing SRV were diluted 1 in $3(\mathrm{v} / \mathrm{v})$ or more in phosphate buffered saline (PBS) $p \mathrm{H} \mathrm{7.2}$ and passed through $0.45-\mu \mathrm{m}$ membrane filters. Gnotobiotic calves aged 1-42 days (Dennis, Davies and Hoare, 1976) were given 3-6 ml of each filtrate intranasally or by mouth. Faecal samples were taken before virus inoculation and daily thereafter.

Received 3 Jan. 1978; revised version accepted 1 Mar. 1978.

J. MED. MICROBIOL.-VOL. 11 (1978) 
To separate SRV from the rotavirus present in one faeces sample, a calf was immunised by inoculation with tissue culture-adapted calf rotavirus (Bridger and Woode, 1975) that had been passaged once in a gnotobiotic calf, and then challenged 3 weeks later with the rotavirus-SRV mixture. The calf developed diarrhoea after both inoculations, but only SRV (sample 1) were excreted after the challenge inoculation. To separate SRV from the coronavirus present in the second faeces sample, the mixture of viruses was passaged in a gnotobiotic calf and the coronavirus excreted in the faeces was inactivated with ether and nonidet. One $\mathrm{ml}$ of faeces was diluted with $50 \mathrm{ml}$ of PBS and, after centrifugation at $8000 \mathrm{~g}$ for $30 \mathrm{~min}$., the supernate was passed through clarifying and $1.2-\mu \mathrm{m}$ membrane filters; it was then mixed with an equal volume of analar diethyl ether and mechanically shaken for $10 \mathrm{~min}$. The aqueous layer was removed and ether extraction repeated twice. Remaining ether was allowed to evaporate from the final aqueous layer before nonidet P-40 at a final concentration of $1 \%(\mathrm{v} / \mathrm{v})$ was added. After passage through a $0.45-\mu \mathrm{m}$ membrane filter, $4 \mathrm{ml}$ of this preparation (SRV sample 2) was instilled intranasally into two gnotobiotic calves. Both calves developed diarrhoea and SRV, but not coronavirus, were excreted in the faeces (SRV sample 2a from one calf, and SRV sample $2 \mathrm{~b}$ from the second calf). Further passages of SRV samples 1 and 2 ( $a$ and $b$ ) in gnotobiotic calves confirmed that they were no longer contaminated with rotavirus and coronavirus respectively. The original faeces sample in which SRV, but neither rotavirus nor coronavirus, was found was designated SRV sample 3.

For cross-protection studies, SRV sample 1, 2 or 3 was given by mouth to a gnotobiotic calf aged 21 days; 3 weeks later, after clinical recovery, the calf was given the same or one of the other two SRV preparations, by mouth.

Antiserum production. Serum samples were taken from the experimentally infected calves before virus inoculation and 3-4 weeks later.

Antiserum to a human astrovirus was kindly supplied by Dr J. B. Kurtz (Public Health Laboratory Service, Oxford).

$D$-xylose absorption test. Seventeen hours after the last feed, gnotobiotic calves were given by mouth $25 \mathrm{~g}$ of D-xylose (BDH Chemicals Ltd) dissolved in $500 \mathrm{ml}$ of water and filtered through $0.45-\mu \mathrm{m}$ membrane filters. Milk was withheld for a further $4 \mathrm{~h}$. In three of the six calves used, the test was applied 1-3 days before inoculation with virus, on the first day of diarrhoea and again 10 days later.

D-xylose in the blood was assayed by the method of Roe and Rice (1948). Heparinised blood samples were taken immediately before D-xylose was fed and at hourly intervals thereafter. The plasma was separated and deproteinised: $0.4 \mathrm{ml}$ of plasma was diluted in $2.8 \mathrm{ml}$ water, and $0.4 \mathrm{ml}$ of a $10 \%$ solution $(\mathrm{w} / \mathrm{v})$ of $\mathrm{ZnSO}_{4} 7 \mathrm{H}_{2} \mathrm{O}$ and $0.4 \mathrm{ml}$ of $0.5 \mathrm{~N} \mathrm{NaOH}$ were added. One $\mathrm{ml}$ of the supernatant fluid was added to $5 \mathrm{ml}$ of $2 \%(\mathrm{w} / \mathrm{v}) p$-bromoaniline (anhydrous, grade I; Sigma Chemical Co.) in glacial acetic acid saturated with thiourea (BDH Chemicals Ltd). The tubes were held at $70^{\circ} \mathrm{C}$ for $10 \mathrm{~min}$. and then cooled and held at $20^{\circ} \mathrm{C}$ for $70 \mathrm{~min}$. in the dark. The reaction was read in a spectrophotometer (Uvichem; Hilger and Watts) at $520 \mathrm{~nm}$. Control tubes included a standard that consisted of $10 \mathrm{mg}$ D-xylose in $100 \mathrm{ml}$ benzoic acid, a water " blank", and an unheated mixture of each plasma sample with the bromoaniline stain. The results were read against the water "blank" and unheated preparations. The concentration of xylose in each blood sample was calculated from the following equation.

$$
\frac{\text { Reading of unknown }}{\text { Reading of } 10 \mathrm{mg} \text { standard }} \times 100=\mathrm{mg} \text { D-xylose per } 100 \mathrm{ml} \text { blood. }
$$

Pathology. Tissues for histopathological examination were removed under pentobarbitone sodium anaesthesia. A short portion of small intestine from each of five equally spaced regions of the gut was tied off and filled with $12 \%$ neutral buffered formalin before removal. The first portion was removed from a site $c .50 \mathrm{~cm}$ from the ileo-caecal junction. and the fifth from a site $c .100 \mathrm{~cm}$ from the pyloric sphincter. Fixation was completed by immersion in fixative. Two or three blocks of fixed tissue from each portion were dehydrated and embedded in paraffin wax; sections were cut at $5 \mu \mathrm{m}$ and stained with haematoxylin and eosin. Villus-crypt ratio determinations were made by selecting from each section 5-8 villi 
that had been sectioned through their entire length; these were measured with an ocular micrometer.

For immunofluorescent studies, a further short portion of intestine was removed from each of the five regions of the gut (see above) and frozen in liquid nitrogen; sections were then cut and fixed in acetone. Each section was stained by the indirect method with convalescent serum and fluorescein-conjugated rabbit antiserum to bovine gamma globulin (Nordic Laboratories).

For electronmicroscopy, a further short portion of intestine from each of the five regions

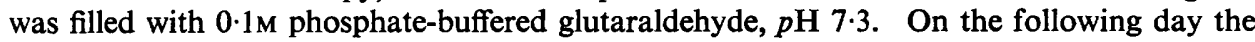
glutaraldehyde-fixed tissue was immersed for $2 \mathrm{~h}$ in $1 \%$ phosphate-buffered osmium tetroxide solution, $p \mathbf{H} 7 \cdot 3$, and dehydrated through graded alcohols. Blocks were embedded in araldite with the villi orientated for longitudinal sectioning. From these blocks $1-\mu \mathrm{m}$ sections were cut, stained with toluidine blue and examined with a light microscope to check the orientation. Ultra-thin sections were cut with a Reichert OMU2 ultramicrotome, stained with uranyl acetate and lead citrate, and examined by means of a Philips EM 300 electron microscope with an accelerating voltage of $60 \mathrm{kV}$ or $80 \mathrm{kV}$.

Tissue culture. Primary calf-kidney (CK) and calf testicular (CT) cell cultures were prepared in tubes with flying coverslips. The growth medium used was Earle's salt solution with lactalbumin hydrolysate (Nutritional Biochemicals) $0.5 \%(\mathrm{w} / \mathrm{v})$, heated $\left(56^{\circ} \mathrm{C}, 1 \mathrm{~h}\right)$ foetal calf serum $10 \%(\mathrm{v} / \mathrm{v})$ and, in place of glucose, galactose $0.1 \%(\mathrm{w} / \mathrm{v})$. For maintenance of infected cultures, $3 \%$ foetal calf serum was used. For titration of virus, dilutions were made in PBS ( $p \mathrm{H} \mathrm{7.2)}$ and $0.2 \mathrm{ml}$ of each dilution was inoculated into $1.8 \mathrm{ml}$ of medium in each coverslip tube.

Virus isolation in tissue culture. Bacteria-free preparations of faeces and intestinal contents from gnotobiotic calves were inoculated into cell cultures to give a final dilution of 1 in 30 and 10-fold dilutions thereof to 1 in 30000 . One to seven days after inoculation, the cultures were fixed in acetone and examined for evidence of infection by immunofluorescence, with gnotobiotic calf antisera to the three SRV preparations. In attempts to culture the viruses, the preparations were passaged four times, both with and without foetal calf serum in the medium, by inoculation of tissue culture fluid containing cells scraped from the glass. The cultures were incubated, either with or without rolling, at $35-36^{\circ} \mathrm{C}$.

Serology. Sera were tested by the indirect immunofluorescent-antibody (FA) technique, with fluorescein-conjugated rabbit antiserum to bovine gamma globulin (Nordic Laboratories), against viral antigens in tissue culture. In an antibody survey 59 serum samples from cows in 22 herds in England and Scotland were tested at a 1 in 10 dilution in PBS, by the FA technique.

Virus detection by electronmicroscopy. Approximately $5 \mathrm{ml}$ of faeces were mixed well with three volumes of PBS. After centrifugation twice at $8000 \mathrm{~g}$ for $30 \mathrm{~min}$., the supernatant fluid was centrifuged at $100000 \mathrm{~g}$ for $2 \mathrm{~h}$. The resulting pellet was layered on top of a sucrose "cushion" consisting of $4 \mathrm{ml}$ of $30 \%(\mathrm{w} / \mathrm{w})$ and $4 \mathrm{ml}$ of $40 \%(\mathrm{w} / \mathrm{w})$ sucrose solution, and centrifuged at $83000 \mathrm{~g}$ for $2 \mathrm{~h}$. The pellet was resuspended in a few drops of PBS; a drop of the suspension was placed on a carbon-formvar electron-microscope grid and examined after staining with $2 \%$ potassium phosphotungstate, $p \mathrm{H} 6 \cdot 0$.

\section{RESULTS}

\section{Animal inoculation}

Twenty-nine of 33 gnotobiotic calves inoculated by mouth with SRV sample 1, 2 or 3 developed diarrhoea (tables I and II). In preliminary studies it had been observed that calves inoculated by mouth with rotavirus and then inoculated 3 weeks later with a SRV preparation developed diarrhoea. In contrast, calves inoculated at 1-8 days of age with a SRV preparation had little or no diarrhoea. To test whether age or a previous episode of enteritis was 


\section{TABLE I}

Production of diarrhoea and excretion of virus by calves inoculated with SRV samples 1,2 and 3

\begin{tabular}{|c|c|c|c|c|c|}
\hline \multirow[b]{2}{*}{$\begin{array}{c}\text { Calf } \\
\text { no. }\end{array}$} & \multirow[b]{2}{*}{$\begin{array}{l}\text { Age } \\
\text { of calf } \\
\text { (days) }\end{array}$} & \multirow[b]{2}{*}{ Inoculum } & \multirow[b]{2}{*}{ Diarrhoea } & \multicolumn{2}{|c|}{ Viruses in faeces } \\
\hline & & & & $\begin{array}{l}\text { as shown by } \\
\text { immuno- } \\
\text { fluorescence } \\
\text { in tissue } \\
\text { cultures }\end{array}$ & $\begin{array}{l}\text { as shown by } \\
\text { electron- } \\
\text { microscopy }\end{array}$ \\
\hline $\begin{array}{l}1 \\
2 \\
3 \\
4 \\
5\end{array}$ & $\begin{array}{r}5 \\
7 \\
3 \\
21 \\
7\end{array}$ & $\begin{array}{l}\text { SRV sample } 1 \\
\text { SRV sample } 1 \text { P1 } \\
\text { SRV sample } 1 \text { P2 } \\
\text { SRV sample } 1 \text { P2 } \\
\text { SRV sample } 1 \text { P3 }\end{array}$ & $\begin{array}{l}+ \\
+ \\
+ \\
+ \\
+\end{array}$ & $\begin{array}{l}+ \\
+ \\
+ \\
+ \\
+\end{array}$ & $\begin{array}{l}\text { SRV } \\
\text { A+C } \\
\text { SRV } \\
A+C \\
A+C\end{array}$ \\
\hline $\begin{array}{r}6 \\
7 \\
8 \\
9 \\
10 \\
11 \\
12 \\
13 \\
14 \\
15 \\
16 \\
17 \\
18 \\
19\end{array}$ & $\begin{array}{r}21 \\
3 \\
20 \\
19 \\
28 \\
21 \\
25 \\
21 \\
21 \\
25 \\
21 \\
19 \\
20 \\
28\end{array}$ & $\begin{array}{l}\text { SRV sample 2a } \\
\text { SRV sample 2a } \\
\text { SRV sample 2a } \\
\text { SRV sample 2a P1 } \\
\text { SRV sample 2a P2 } \\
\text { SRV sample 2a P3 } \\
\text { SRV sample 2a P3 } \\
\text { SRV sample 2a P3 } \\
\text { SRV sample 2a P3 } \\
\text { SRV sample 2a P3 } \\
\text { SRV sample 2a P3 } \\
\text { SRV sample 2a P3 } \\
\text { SRV sample 2c } \\
\text { SRV sample 2c P1 }\end{array}$ & $\begin{array}{l}+ \\
+ \\
+ \\
+ \\
+ \\
+ \\
+ \\
+ \\
+ \\
+ \\
+ \\
+ \\
+\end{array}$ & $\begin{array}{l}\text { NT } \\
- \\
- \\
- \\
- \\
- \\
- \\
- \\
- \\
+\end{array}$ & $\begin{array}{l}\text { C } \\
\text { C } \\
\text { C } \\
\text { C } \\
\text { C } \\
\text { C } \\
\text { C } \\
\text { C } \\
\text { C } \\
\text { C } \\
\text { C } \\
\text { C } \\
\text { A } \\
\text { A }\end{array}$ \\
\hline $\begin{array}{l}20 \\
21 \\
22 \\
23 \\
24 \\
25 \\
26 \\
27\end{array}$ & $\begin{array}{r}8 \\
6 \\
40 \\
35 \\
1 \\
20 \\
21 \\
21\end{array}$ & $\begin{array}{l}\text { SRV sample } 3 \\
\text { SRV sample } 3 \\
\text { SRV sample } 3 \text { P1 } \\
\text { SRV sample } 3 \text { P1 } \\
\text { SRV sample } 3 \text { P1 } \\
\text { SRV sample } 3 \text { P1 } \\
\text { SRV sample } 3 \text { P2 } \\
\text { SRV sample } 3 \text { P2 }\end{array}$ & $\begin{array}{l}+ \\
+ \\
+ \\
+ \\
+ \\
+ \\
+\end{array}$ & $\begin{array}{l}+ \\
+ \\
+ \\
+ \\
\text { NT } \\
+ \\
+\end{array}$ & $\begin{array}{l}\text { A+C } \\
\text { NT } \\
\text { NT } \\
\text { A+C } \\
\text { NT } \\
\text { SRV } \\
\text { A+C } \\
\text { NT }\end{array}$ \\
\hline
\end{tabular}

$\mathrm{SRV}=$ Small round viruses, type not determined; $\mathrm{A}=$ astrovirus-like particles; $\mathrm{C}=$ caliciviruslike particles; $\mathrm{NT}=$ not tested.

$+=$ Present; $\pm=$ slight; $-=$ absent.

\section{TABLE II}

Cross-protection studies in calves with $S R V$ samples 1,2 and 3

\begin{tabular}{c|ccc}
\hline $\begin{array}{c}\text { SRV sample } \\
\text { with which } \\
\text { calves were } \\
\text { immunised }\end{array}$ & $\begin{array}{c}\text { Cross-protection in calves challenged } \\
\text { 3 weeks later with SRV sample }\end{array}$ \\
\hline 1 & 1 & 2 & 3 \\
2 & $\begin{array}{l}+(29,30) \\
+(31,34) \\
+(27)\end{array}$ & $\begin{array}{l}+(5) \\
+(7) \\
+(26)\end{array}$ & $\begin{array}{l}-(4) \\
-(28,12) \\
+(24)\end{array}$ \\
\hline
\end{tabular}

$+=$ Cross-protection occurred; $-=$ no cross-protection occurred

Identification numbers of calves are given in parenthesis. 
the more important factor in regard to the occurrence of illness, gnotobiotic calves were inoculated by mouth with SRV sample 1, 2 or 3 at 19-28 days of age. All calves, particularly those inoculated with SRV sample 2, developed profuse yellow diarrhoea, depression and anorexia after an incubation period of 1-3 days.

As the three SRV preparations had been obtained from three separate epizootics of calf diarrhoea, cross-protection studies were made in calves to test whether the pathogens present in SRV samples 1, 2 and 3 were related (table II).

SRV sample 3 protected against all three samples, while SRV sample 2 did not prevent infection with sample 1 or 3 . Sample 1 protected against itself and sample 2, but did not protect calf no. 4 against infection with sample 3 . From these results it followed that sample 3 possessed at least three different pathogens, sample 1 at least two, and sample 2 at least one. To test whether sample 3 possessed pathogens other than those in samples 1 and 2, calf no. 33 was inoculated by mouth at 17 days of age with SRV samples 1 and 2, and 3 weeks later with sample 3 . The calf developed diarrhoea after the first inoculation, but not after the second. This result was not consistent with those obtained earlier and further work is required to determine whether antigenically different viral pathogens are present in the three preparations.

\section{Cell culture studies}

Attempts to adapt the viruses to cell culture were unsuccessful. However, all three preparations infected CK and CT cell cultures with the production of intracellular specific antigen that immunofluoresced with convalescent sera to all three SRV samples (fig. 1). This indicated that all three samples contained antigenically related viruses. There was no cross-reaction with gnotobiotic calf antiserum to bovine rotavirus, bovine coronavirus, or bovine pestivirus (mucosal disease virus), or with antiserum to human astrovirus; the latter produced immunofluorescence, similar to that described above, in human kidney-cell cultures. The number of immunofluorescent cells was highest when cultures were fixed 48-72 h after infection, but a few immunofluorescent cells were present 7 days after infection. One passage of the infected cultures invariably resulted in complete loss of ability to produce immunofluorescent foci.

\section{Electronmicroscopy}

Small round virus-like particles about $30 \mathrm{~nm}$ in diameter were seen in each of the preparations of SRV samples 1,2 and 3. These particles were seen after passage of each preparation in gnotobiotic calves, suggesting that they were replicating agents. On closer examination, faecal preparations from infected gnotobiotic calves appeared to contain two types of particle that differed morphologically. The first type consisted of particles with a reticulate appearance and capsomeres projecting from their outer edges; they measured $33 \mathrm{~nm}$ in diameter (fig. 2). Occasionally these particles were penetrated by negative stain and showed an outer rim 7-8 $\mathrm{nm}$ wide. The particles occurred singly, 
but also in groups varying in number from a few to several hundred. Within these groups, smaller particles about $18 \mathrm{~nm}$ diameter and usually penetrated by negative stain, were sometimes seen (fig. 2). In respect of its size and of the lacelike appearance of its edges, the 33-nm particle resembled a calicivirus, but as it has not been characterised as such, we have called it the "Newbury agent".

Particles of the second type were morphologically dissimilar to the Newbury agent. Their outer edges were more clearly defined and their diameters averaged $28 \mathrm{~nm}$. Their surface structure was distinct from the Newbury agent and on some particles a six-pointed star pattern was visible (fig. 3). They were indistinguishable ( $\mathrm{Dr}$ C. R. Madeley, personal communication) from the particles reported in human faeces and named astroviruses (Madeley and Cosgrove, 1975), and we have therefore described them as astrovirus-like. They occurred in clumps of varying sizes and when penetrated by negative stain possessed a rim 3-4 $\mathrm{nm}$ wide.

\section{Separation of the Newbury agent and the astrovirus-like agent}

By electronmicroscopy, the preparation of SRV sample 2a appeared to contain only the Newbury agent, whereas SRV sample $2 b$ contained particles of both types. When SRV sample 2a was passaged serially in gnotobiotic calves (nos. 9-17) only the Newbury agent was observed and all the calves developed diarrhoea. Immunofluorescence was not observed in CK cells $48 \mathrm{~h}$ after inoculation with faecal preparations from calves 9-17. The calf that excreted only the Newbury agent (SRV sample 2a) had been inoculated previously at 3 days of age with SRV sample 1 (see calf 3 in table I); it did not develop diarrhoea but excreted both Newbury agent and astrovirus-like particles. When the calf was inoculated 3 weeks later with SRV sample 2, it excreted only Newbury agent particles; this implied that the first inoculum had produced an immunity against the astrovirus-like, immunofluorescent agent. Newbury agent antiserum produced in calf 9 during convalescence did not immunofluoresce with tissue cultures infected with preparations containing the astrovirus-like agent from SRV samples $1,2 b$ and 3 .

To separate the astrovirus-like agent from the Newbury agent, calf 8 was inoculated with SRV sample 2a which contained the Newbury agent, and 3 weeks later with SRV sample $2 b$, which contained both the Newbury and astrovirus-like agents. This calf did not develop diarrhoea after the second inoculation and excreted only the astrovirus-like particles (SRV sample 2c). Sample 2c was passaged serially in gnotobiotic calves 18 and 19, neither of which developed diarrhoea, but both of which excreted the astrovirus-like particles. Faecal preparations from these calves infected CK cell cultures as was shown by the immunofluorescence obtained with antisera to SRV samples 1 and 3 (from calves 4,24 and 25) and with convalescent antiserum from calf 18 . Excretion of the astrovirus-like agent was demonstrable, at least until the 5th day after infection.

From these limited experiments we concluded that the astrovirus-like agent immunofluoresced in cell culture and infected calves, but did not cause diarrhoea 
or clinical illness in gnotobiotic calves. In contrast, the Newbury agent did not infect CK cell cultures, but did cause diarrhoea and clinical illness in all 12 calves inoculated (calves 6-17). These conclusions are based on the virus particles observed in SRV sample 2.

\section{Serological survey}

Sixteen of 59 blood samples, and 11 of 22 herds, were serologically positive by the FA test to the astrovirus-like agent. These serum samples were taken from farms in England and Scotland.

\section{D-xylose malabsorption}

Calves 13-17, which were infected with the Newbury agent, showed a reduction in absorption of D-xylose of $60-100 \%$ on the day of onset of diarrhoea, as compared with the absorption rate before virus inoculation (fig. 4). D-xylose absorption by the calves had returned almost to normal 10 days after infection. The faeces of calf 10 changed in colour from dark brown to yellow, but remained relatively solid, and only small quantities were passed. A mild effect was also apparent in the D-xylose absorption test with a barely detectable drop in the absorption rate.

\section{Pathology}

Calves 12-15, inoculated with the Newbury agent, showed macroscopic lesions that were confined to the small intestine; haemorrhagic foci occurred and the villi appeared shortened when viewed under a dissecting microscope. No macroscopic lesions were observed in the stomach, large intestine, liver, lung or kidneys. Microscopically the villi were shortened and thickened, with an increased cellularity of the lamina propria, and capillary dilation occurred. Most villi had normal columnar epithelial cells with normal brush borders, but on some villi the epithelium was lost from the top third and on the other villi the epithelial cells had a cuboidal appearance. No abnormal cells were observed by electron-microscopical studies of thin sections of intestinal villi, although in certain areas the microvilli appeared shortened or in disarray. Virus particles were not observed in cells. The histopathological lesions were most prominent in the middle (region 3) of the small intestine. No immunofluorescence was observed in the small intestine of infected calves, with convalescent antisera to the Newbury or astrovirus-like agents.

The villous lengths and crypt depths in calves (nos. 12-15) inoculated with the Newbury agent, were compared morphometrically with two control calves, and with two calves (nos. 19 and 35) inoculated with the astrovirus-like agent and with rotavirus respectively (table III). Calf 19 was killed 5 days after infection for post-mortem examination. Calf 35 developed diarrhoea, was depressed and anorexic. The ratios (villus : crypt) for calves 12-15 were lower than those of the control calves and similar to those of calf 35. Macroscopic lesions were not observed in the small intestine of calf 19 although there was a reduction in the villus-to-crypt ratio in the middle region (region 3). Villi in this region were thickened, with an increased cellularity of the lamina propria. 

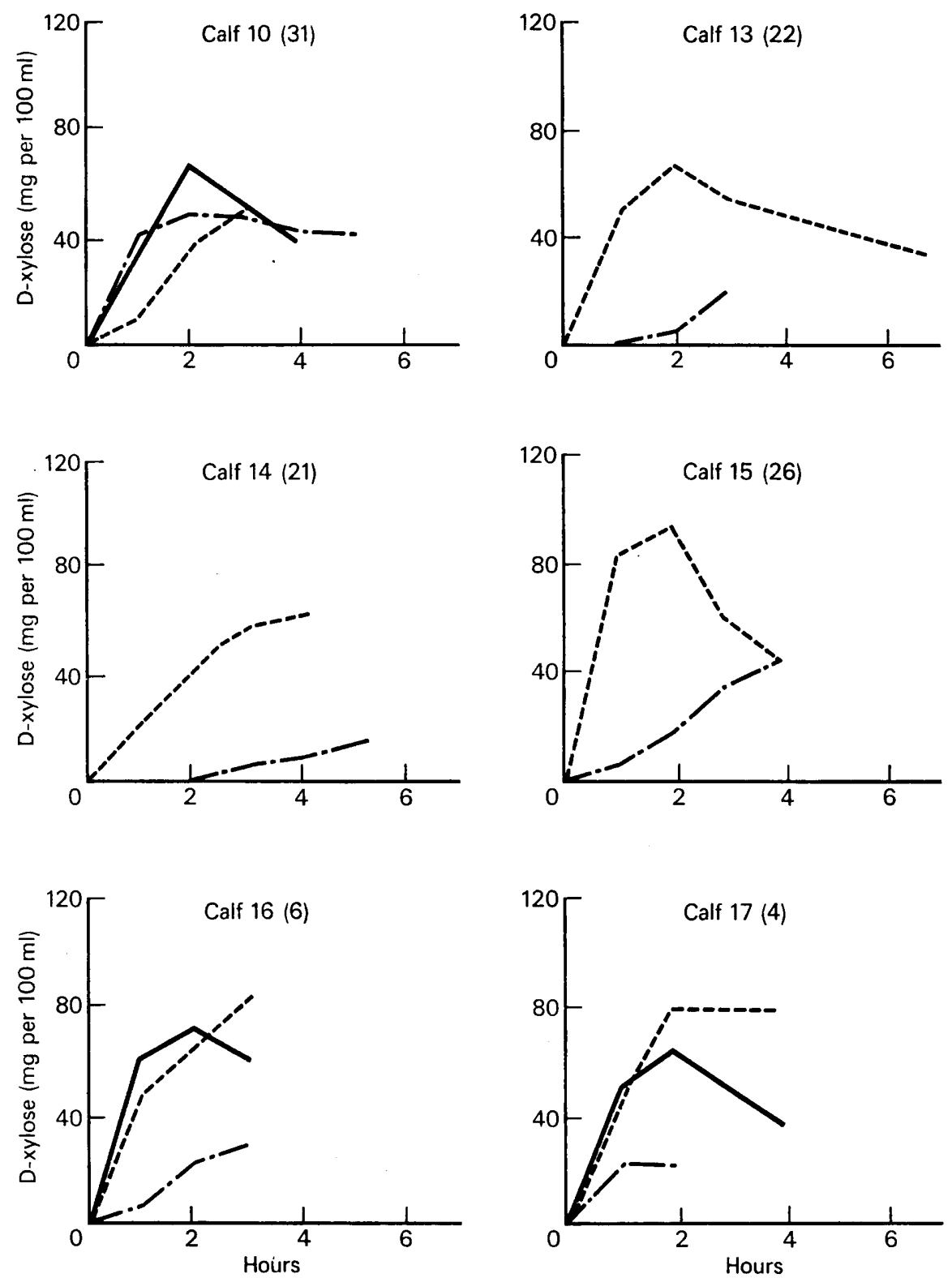

FIG. 4.-Blood D-xylose levels in calves infected with the Newbury agent. $\ldots . .$. - Before virus inoculation; $---=$ on day of onset of diarrhoea; -10 days after diarrhoea. The ages of the calves (in days) are given in parenthesis.

In other regions the villus-to-crypt ratios differed only slightly from those observed in the control calves.

\section{Discussion}

The "Newbury agent" was pathogenic to the gnotobiotic calves as judged by histopathological examination and by the malabsorption of D-xylose in 
TABLE III

Villus-to-crypt ratios of calves infected with the Newbury agent, astrovirus-like agent or calf rotavirus

\begin{tabular}{|c|c|c|c|c|c|c|c|}
\hline Calf no. & $\begin{array}{c}\text { Age } \\
\text { (days) at } \\
\text { post-mortem } \\
\text { examination }\end{array}$ & $\begin{array}{l}\text { Virus } \\
\text { inoculum }\end{array}$ & $\begin{array}{l}\text { Region* } \\
\text { of small } \\
\text { intestine } \\
\text { from } \\
\text { which } \\
\text { tissue was } \\
\text { taken }\end{array}$ & $\begin{array}{c}\text { Average } \\
\text { villous } \\
\text { length } \\
(\mu \mathrm{m})\end{array}$ & $\begin{array}{c}\text { Average } \\
\text { crypt } \\
\text { depth } \\
(\mu \mathrm{m})\end{array}$ & $\begin{array}{l}\text { Average } \\
\text { villus-to- } \\
\text { crypt } \\
\text { ratio }\end{array}$ & $\begin{array}{l}\text { Range of } \\
\text { villus-to-crypt } \\
\text { ratios }\end{array}$ \\
\hline Control 1 & 28 & None & $\begin{array}{l}5 \\
3 \\
1\end{array}$ & $\begin{array}{l}505 \\
640 \\
460\end{array}$ & $\begin{array}{l}150 \\
150 \\
125\end{array}$ & $\begin{array}{l}3 \cdot 7 \\
4 \cdot 3 \\
3 \cdot 7\end{array}$ & $\begin{array}{l}5 \cdot 5-2 \cdot 8 \\
5 \cdot 0-4 \cdot 0 \\
4 \cdot 0-2 \cdot 7\end{array}$ \\
\hline Control 2 & 47 & None & $\begin{array}{l}5 \\
3 \\
1\end{array}$ & $\begin{array}{r}970 \\
1000 \\
760\end{array}$ & $\begin{array}{l}230 \\
180 \\
190\end{array}$ & $\begin{array}{l}4 \cdot 2 \\
6 \cdot 5 \\
4 \cdot 0\end{array}$ & $\begin{array}{r}4 \cdot 3-3 \cdot 7 \\
10 \cdot 8-4 \cdot 5 \\
5 \cdot 3-3 \cdot 2\end{array}$ \\
\hline 12 & 28 & $\begin{array}{l}\text { Newbury } \\
\text { agent } \\
\text { (SRV sample } \\
\text { 2a) }\end{array}$ & $\begin{array}{l}5 \\
4 \\
3 \\
2 \\
1\end{array}$ & $\begin{array}{l}500 \\
590 \\
600 \\
570 \\
490\end{array}$ & $\begin{array}{l}300 \\
320 \\
320 \\
280 \\
240\end{array}$ & $\begin{array}{l}1.7 \\
1.8 \\
1.9 \\
2.0 \\
2.0\end{array}$ & $\begin{array}{l}2 \cdot 5-1 \cdot 3 \\
2 \cdot 4-1 \cdot 4 \\
2 \cdot 0-1 \cdot 25 \\
2 \cdot 8-1 \cdot 3 \\
2 \cdot 5-1 \cdot 6\end{array}$ \\
\hline 19 & 33 & $\begin{array}{l}\text { Astrovirus- } \\
\text { like agent } \\
\text { (SRV sample } \\
\text { 2c) }\end{array}$ & $\begin{array}{l}5 \\
4 \\
3 \\
2 \\
1\end{array}$ & $\begin{array}{r}1220 \\
980 \\
700 \\
670 \\
600\end{array}$ & $\begin{array}{l}310 \\
200 \\
280 \\
200 \\
200\end{array}$ & $\begin{array}{l}4 \cdot 0 \\
5 \cdot 0 \\
2 \cdot 5 \\
3 \cdot 3 \\
3 \cdot 0\end{array}$ & $\begin{array}{l}4 \cdot 8-3 \cdot 1 \\
5 \cdot 6-4 \cdot 0 \\
2 \cdot 8-2 \cdot 0 \\
4 \cdot 0-2 \cdot 8 \\
3 \cdot 1-2 \cdot 0\end{array}$ \\
\hline 35 & 28 & Rotavirus & $\begin{array}{l}5 \\
4 \\
3 \\
2 \\
1\end{array}$ & $\begin{array}{l}280 \\
250 \\
280 \\
460 \\
490\end{array}$ & $\begin{array}{l}250 \\
230 \\
250 \\
250 \\
340\end{array}$ & $\begin{array}{l}1 \cdot 1 \\
1.0 \\
1 \cdot 1 \\
1.8 \\
1.4\end{array}$ & $\begin{array}{l}1.5-0.7 \\
1.5-0.8 \\
1.5-0.8 \\
2.25-1.4 \\
1.5-1.25\end{array}$ \\
\hline
\end{tabular}

* See Materials and methods.

addition to its ability to produce diarrhoea in the 12 calves inoculated. Only two gnotobiotic calves were inoculated with the astrovirus-like agent, and further studies will be required to decide whether it is non-pathogenic. One of the two calves, although not developing diarrhoea, had mild villous atrophy in the middle region of the small intestine and the villi appeared abnormal histologically. It is possible that certain astrovirus-like agents will prove to be pathogenic, particularly in conventionally reared calves, just as some rotaviruses are avirulent and others virulent for gnotobiotic piglets (Woode et al., 1976). The studies on the Newbury and astrovirus-like agents were limited to viruses present in only one of the three samples of SRV, and the cross-protection studies imply that there was more than one pathogenic agent in these three preparations. At present no antigenic test is available to study the Newbury agent in the three preparations, but the FA test showed the close relationship in the three samples of the "fluorescent" agent, which appears to be the astrovirus-like agent. The 
immunofluorescence of this agent was similar in appearance to that produced in cell culture by the human astrovirus (Lee and Kurtz, 1977) although the two agents do not share immunofluorescent antigens.

The Newbury agent is being studied further to determine whether it should be classified as a calicivirus. In our opinion its morphology is not identical to that of other caliciviruses, as the detailed structure reported by Almeida et al. (1968) was not visible clearly, although the particles resembled the morphology of some of the feline calicivirus isolates described by Zwillenberg and Bürki (1966).

The morphometric analysis of the villous lesion and the D-xylose malabsorption have proved to be good methods for measuring objectively the virulence of enteric viruses. The villus-to-crypt ratios of the diarrhoeic calves were different from those of the control calves and of the calf infected with the astrovirus-like agent. Rotavirus infection appears to us to be slightly more severe than that associated with the SRV, in terms both of clinical severity and of malabsorption (Woode, Smith and Dennis, 1978).

The killing of animals for histopathological study is often disadvantageous in other respects. For this reason, D-xylose malabsorption, glucose malabsorption or lactose tolerance tests are useful. The absorption rate can be determined before, during and after clinical illness. Because there is no background blood level of D-xylose, good absorption curves can be obtained. D-xylose, a pentose, is absorbed by the same route as glucose, partly by a passive and partly by an active process (Roberts, 1974).

Malabsorption of D-xylose has been studied in dogs and horses suffering from enteric syndromes (Hill, Kidder and Frew, 1970; Roberts, 1974) and in human beings and gnotobiotic calves infected with rotaviruses (Mavromichalis et al., 1977; Woode, Smith and Dennis, 1978). Rotaviruses and SRV cause severe malabsorption, but signs of recovery are apparent 10 days after infection. Malabsorption of D-xylose might result from retention of food in the rumen, omasum or abomasum of an infected calf or be due to a reduced transit time in the small intestine when the animal has diarrhoea. However, the malabsorption correlates well with a loss of the absorptive cells of the upper part of the villi of the small intestine, and it is reasonable to conclude that the D-xylose absorption rate is an indirect measure of the absorptive ability of the villi.

Our failure to find evidence of viral infection in the small intestine by immunofluorescence and electronmicroscopy may have been because infected cells were lost from the villi before the time of examination. It has been observed in rotavirus infections of lambs and pigs that the immunofluorescence of villi is maximal before villous atrophy develops (Snodgrass, Angus and Gray, 1977; Crouch and Woode, 1978).

It is commonly believed that bovine enteritis viruses are pathogenic mainly for newborn or very young animals. However, bovine rotavirus caused diarrhoea in gnotobiotic calves 5 weeks of age, and natural infection, with diarrhoea, has been observed in cattle of all ages (Woode and Bridger, 1975; Woode, Bew and Dennis, unpublished). Likewise, these small viruses, although 
SMALL VIRUSES FROM CALF ENTERITIS
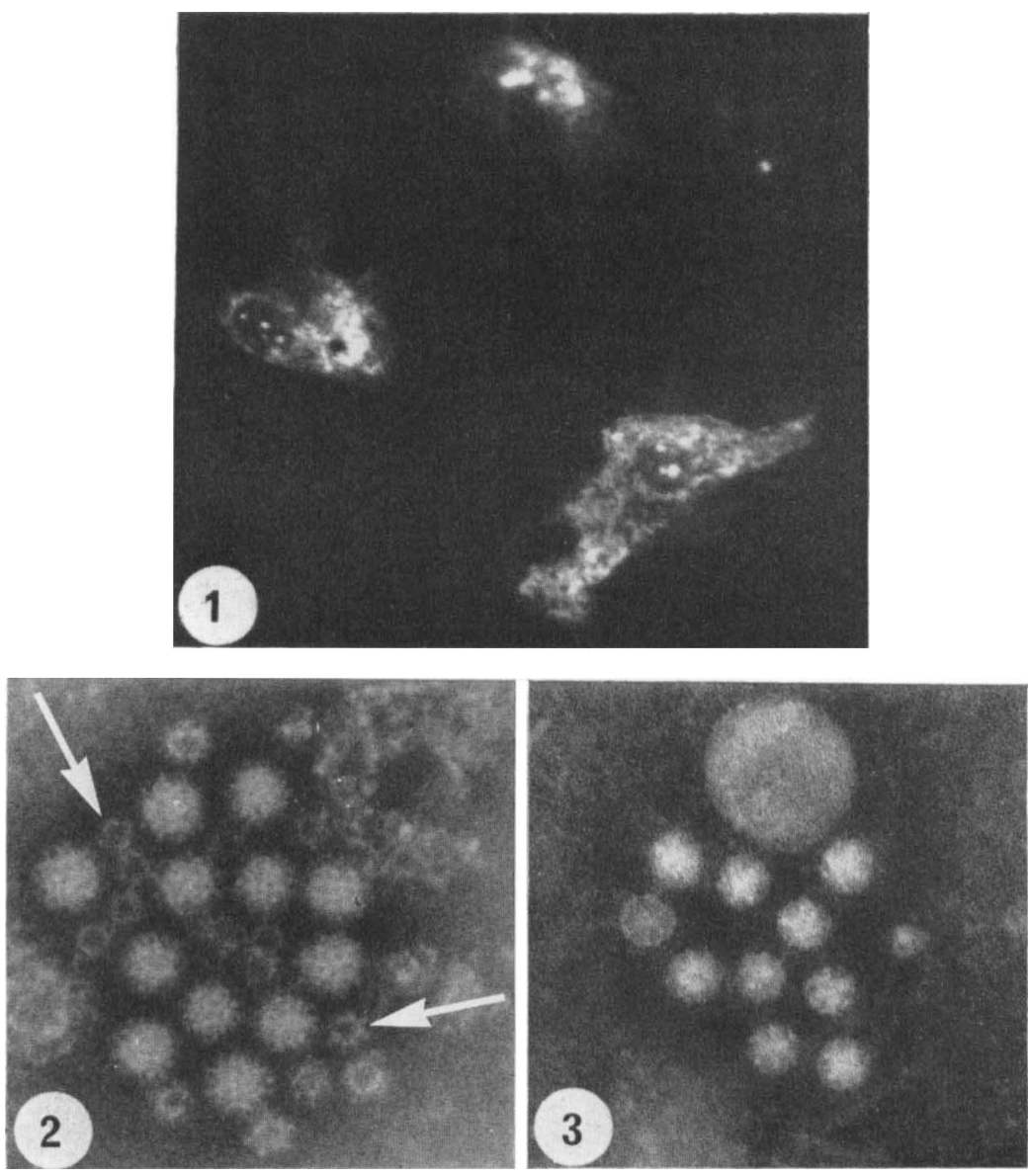

FIG, 1.-Immunofluorescence in primary calf-kidney cells infected with the astrovirus-like agent. $\times 1125$.

FIG. 2.-Negatively stained particles in the diarrhoeic faeces of a gnotobiotic calf infected with the Newbury agent (calicivirus-like). The 18-nm diameter particles often found associated with the Newbury agent are indicated by arrows. Electronmicrograph (EM). $\times 220000$.

FIG. 3.-Negatively stained particles in the faeces of a gnotobiotic calf infected with the astroviruslike agent. EM. $\times 220000$. 
isolated from calves with diarrhoea during the 1st week of life, were capable of causing diarrhoea in gnotobiotic calves up to at least the 5th week of life. The disease produced by inoculation of SRV was mild in the eight calves aged 1-8 days, compared with that produced in the calves aged 19-40 days.

The Newbury and astrovirus-like agents complicate the virological diagnosis of bovine diarrhoea. It is possible that both are primary pathogens, but in our experience they are commonly found in association with rotavirus or coronavirus, either in the same calf or in the same outbreak. From one calf, which died at 3 days of age, we isolated Salmonella dublin, bovine coronavirus, and both the astrovirus-like and Newbury agents. Our serological survey showed that the astrovirus-like agent was common in the bovine population. The immunofluorescence of cells in cell cultures infected with the astroviruslike agent was indistinguishable in appearance from that in cells infected with rotavirus. Thus, for diagnostic and experimental purposes, it is important to be certain that the antiserum used is monospecific. The problems of coronavirus diagnosis have been discussed recently (Woode et al., 1978) and the diagnosis of SRV infection presents similar problems, namely difficulty in culturing the agents and in characterising them antigenically. Experience with rotaviruses suggests that the electron-microscopical diagnosis of coronavirus and SRV infection is probably many times less sensitive than diagnosis by animal inoculation.

\section{SUMMARY}

Small round viruses (SRV) were isolated from the faeces of diarrhoeic calves from three farms. All three SRV preparations caused diarrhoea experimentally in gnotobiotic calves. Each preparation contained viral particles of two morphological types, " astrovirus-like" and "calicivirus-like", and from one preparation the two particle types were separated from each other. The calicivirus-like agent ("Newbury agent ") was $33 \mathrm{~nm}$ in diameter, and caused diarrhoea in gnotobiotic calves, with villous atrophy and D-xylose malabsorption. This virus did not infect cell cultures. The astrovirus-like agent did not cause diarrhoea in two gnotobiotic calves; however, it infected cell cultures (primary calf kidney) and the infected cells immunofluoresced with convalescent gnotobiotic-calf antiserum. The astrovirus-like agents in the three preparations were antigenically related. Experiments in calves showed that there was a degree of cross-protection between the three SRV preparations, as judged by the presence or absence of diarrhoea, but that at least three unrelated pathogens were present.

The authors thank Mr M. Dennis for the supply of gnotobiotic calves, Mr D. Luther for the supply of cell cultures, Mr M. Bew, Mr C. Smith and Miss J. F. Brown for laboratory assistance, and $\mathrm{Mr} \mathrm{H}$. Anger for the preparation of intestinal sections for electron-microscopic examination.

\section{REFERENCES}

ACres, S. D., Laing, C. J., SAunders, J. R. AND Radistits, O. M. 1975. Acute undifferentiated neonatal diarrhoea in beef calves. 1. Occurrence and distribution of infectious agents. Can. J. comp. Med., 39, 116.

J. MED. MICROBIOL.-VOL. 11 (1978) 
Almeida, J. D., Waterson, A. P., Prydie, J. and Fletcher, E. W. L. 1968. The structure of a feline picornavirus, and its relevance to cubic viruses in general. Arch. ges. Virusforsch., 25, 105.

BRIDGER, J. C. AND WOODE, G. N. 1975. Neonatal calf diarrhoea: identification of reoviruslike (rotavirus) agent in faeces by immunofluorescence and immune electron microscopy. Br. vet. J., 131, 528.

Bridger, J. C., Woode, G. N. AND Meyling, A. 1978. Isolation of coronaviruses from neonatal calf diarrhoea in Great Britain and Denmark. Vet. Microbiol., in press.

Crouch, C. F. AND Woode, G. N. 1978. Serial studies of virus multiplication and intestinal damage in gnotobiotic piglets infected with rotavirus. J. med. Microbiol., in press.

DenNis, M. J., Davies, D. C. AND HoARE, M. N. 1976. A simplified apparatus for the microbiological isolation of calves. Br. vet. J., 132, 642 .

Flewett, T. H. AND WoOde, G. N. 1978. The rotaviruses. Archs Virol., 56, in press.

HILl, F. W. G., KIDDER, D. E. AND Frew, J. F. 1970. A xylose absorption test for the dog. Vet. Rec. 87, 250.

LeE, T. W. AND KurTZ, J. B. 1977. Astroviruses detected by immunofluorescence. Lancet, 2, 406.

MAdeley, C. R. AND Cosgrove, B. P.1975. Viruses in infantile gastroenteritis. Lancet, 2, 124.

MAdeley, C. R. AND Cosgrove, B. P. 1976, Caliciviruses in man. Lancet, 1, 199.

Madeley, C. R., Cosgrove, B. P., Bell, E. J. and Fallon, R. J. 1977. Stool viruses in babies in Glasgow. 1. Hospital admissions with diarrhoea. J. Hyg., Camb., 78, 261.

Mavromichalis, J., Evans, N., McNeish, A. S., Bryden, A. S., Davies, H. A. and FlewETT, T. H. 1977. Intestinal damage in rotavirus and adenovirus gastroenteritis assessed by D-xylose malabsorption. Archs Dis. Child., 52, 589.

Mebus, C. A., Stair, E. L., Rhodes, M. B. AND Twiehaus, M. J. 1973. Neonatal calf diarrhea: propagation, attenuation and characteristics of a coronavirus-like agent. Am. J. vet. Res., 34, 145.

MoRIN, M., LARIVIÈRE, S. AND LALLIER, R. 1976. Pathological and microbiological observations made on spontaneous cases of acute neonatal calf diarrhoea. Can. J. comp. Med., 40, 228.

RoberTs, M. C. 1974. The D (+) xylose absorption test in the horse. Eq. vet. J., 6, 28.

ROE, J. H. AND RICE, E. W. 1948. A photometric method for the determination of free pentoses in animal tissues. J. biol. Chem., 173, 507.

SCHERrer, R., COHEN, J., L'HARIDON, R., FeYNerol, C. AND FAYET, J. C. 1976. Identification of a rotavirus associated with neonatal calf diarrhoea in France. Bull. Off. int. Épizoot., 85, 23.

Snodgrass, D. R., ANGus, K. W. AND GRAY, E. W. 1977. Rotavirus infection in lambs: pathogenesis and pathology. Archs Virol., 55, 287.

Storz, J. AND Bates, R. C. 1973. Parvovirus infections in calves. J. Am. vet. med. Assoc., $163,884$.

WoodE, G. N. 1969. Transmissible gastroenteritis of swine. Vet. Bull., 39, 239.

Woode, G. N. AND Brimger, J. C. 1975 . Viral enteritis of calves. Vet. Rec., 96, 85.

Woode, G. N., Bridger, J. C., HALl, G. A. AND DenNIS, M. J. 1974. The isolation of a reovirus-like agent associated with diarrhoea in colostrum deprived calves in Great Britain. Res. vet. Sci., 16, 102.

Woode, G. N., Brmger, J. C., Jones, J. M., Flewett, T. H., Bryden, A. S., Davies, H. A. AND WHITE, G. B. B. 1976. Morphological and antigenic relationships between viruses (rotaviruses) from acute gastroenteritis of children, calves, piglets, mice and foals. Infect. Immun., 14, 804.

Woode, G. N., BRIDger, J. C. AND MeYling, A. 1978. Significance of bovine coronavirus infection. Vet. Rec., 102, 15.

Woode, G. N., SMItH, C. AND DenNIS, M. J. 1978. Intestinal damage in rotavirus infected calves assessed by D-xylose malabsorption. Vet. Rec., 102, 340.

ZWILLENBERG, L. O. AND BÜRKI, F. 1966. On the capsid structure of some small feline and bovine RNA viruses. Arch. ges. Virusforsch., 19, 373. 